\title{
The role of informal institutions in corporate governance: Brazil, Russia, India, and China compared
}

\author{
Saul Estrin • Martha Prevezer
}

Published online: 25 September 2010

(C) Springer Science+Business Media, LLC 2010

\begin{abstract}
This paper argues that the role of informal institutions as well as formal ones is central to understanding the functioning of corporate governance. We focus on the four largest emerging economies: Brazil, Russia, India, and Chinacommonly referred to as the BRIC countries. Our analysis is based on the Helmke and Levitsky framework of informal institutions and focuses on two related aspects of corporate governance: firm ownership structures and property rights; and the relationship between firms and external investors. We argue that for China and some states of India, "substitutive" informal institutions, whereby informal institutions substitute for and replace ineffective formal institutions, are critical in creating corporate governance leading to enhanced domestic and foreign investment. In contrast, Russia is characterized by "competing" informal institutions whereby various informal mechanisms of corporate governance associated with corruption and clientelism undermine the functioning of reasonably well set-out formal institutions relating to shareholder rights and relations with investors. Finally Brazil is characterized by "accommodating" informal institutions which get around the effectively enforced but restrictive formal institutions and reconcile varying objectives that are held between actors in formal and informal institutions.
\end{abstract}

Keywords Institutions (informal and formal) · Corporate governance · Shareholder rights · Suppliers of finance $\cdot$ Emerging economies · BRIC

The authors would like to thank Ruta Aidis, Sumon Bhaumik, Nauro Campos, Simon Commander, Klaus Meyer, and Lihui Tian for discussions during the initial development of these ideas. Our thinking was advanced at the APJM Conference on Corporate Governance, October 8th and 9th, 2009 in Vancouver, and especially by discussion of comments from Mike Peng, Danny Shapiro, Phil Phan, and Steve Globerman and an anonymous referee. Any remaining errors are our own.

\footnotetext{
S. Estrin $(\bowtie)$

Department of Management, London School of Economics, London, UK

e-mail: s.estrin@1se.ac.uk
}

M. Prevezer

School of Business and Management, Queen Mary University of London, London, UK

e-mail: m.j.prevezer@qmul.ac.uk 
JEL M21 $\cdot$ L21 P52

This paper sets out to integrate the role of informal institutions into the debate about "good" governance infrastructure and corporate governance for Brazil, Russia, India, and China, often referred to as the BRIC economies (Goldman Sachs, 2003). We use a case study approach to contrast the interaction of formal with informal institutions for two key aspects of corporate governance: ownership structures and property rights; and relations between the firm and external investors. We build on the Helmke and Levitsky (2003) typology of informal institutions which considers the relationship between formal and informal institutions to be dependent on whether formal institutions are effective and on how compatible are the goals of agents in formal and informal institutions. This interaction of formal with informal institutions is argued to condition these key aspects of corporate governance.

Research on emerging economies has emphasized the connection between corporate governance structures and institutional development. Thus Steier (2009) argues that in emerging and developing market economies, family ownership is the predominant mode of governance combined with the remnants of state ownership and financial industrial groupings. The weakness of markets and legal and judicial infrastructure make family ties highly significant and the state can also play an important role in firms' governance. Similarly in transition economies such as Russia, there remains poor definition and enforcement of ownership rights: "changing the law on the books does not guarantee corporate governance improvement" (Licht, Goldschmidt, and Schwartz, 2005: 230, in Steier, 2009). Steier emphasizes the role of corruption and black or grey markets and family or ethnic ties to maneuver through complex and corrupt institutions.

Globerman and Shapiro (2003) argue that the strength of governance infrastructure, such as the functioning of a range of formal institutions including property rights, regulation, transparency of information, and accountability, are important in attracting foreign direct investment (FDI) to developing and transition countries. By governance infrastructure, they mean attributes of legislation, regulation, and transparency of government and legal processes that determine the security of property rights and transparency of government and legal processes. Numerous other papers have identified the importance of national governance infrastructure for growth, investment, and new firm entry (e.g., Acemoglu, Johnson, and Robinson, 2001, Acemoglu, Johnson, and Robinson, 2002; Acemoglu, Johnson, Robinson, \& Thaicharoen, 2003; Acemoglu \& Robinson, 2000; Djankov, La Porta, Lopez-de-Silanes, \& Shleifer, 2002; La Porta, Lopez-de-Silanes, Shleifer, \& Vishny, 1999). These studies are largely based on formal measures of institutions, for example the number of procedures necessary to start a business, which are necessarily coarse as a consequence of the need for comparability across more than 80 countries. Thus, while considerable insight has been derived from this approach, it tends to understate the role of informal institutions and the ways they interact with and may either improve or undermine formal institutions. Yet informal institutions are of especial significance in emerging economies where the functioning of formal corporate governance institutions, such as corporate ownership rights or relations with external investors, are not transparent nor well-enforced. Aguilera, Filatotchev, Gospel, and Jackson (2008) recognize the 
need, in order to understand the effects of corporate governance on the performance of firms, to contextualize and specify the linkages in their open systems perspective between different aspects of the organizational environment. They do not include, however, specifically "informal institutions" in their consideration of costs, contingencies, and complementarities. Peng and Heath (1996) emphasize the larger role that informal constraints play in emerging economies where formal institutions are weak. Peng (2002) also recognizes the importance of the interaction between formal constraints and informal constraints and their effects on organizations in the context of emerging economies in Asia.

In this paper, we develop a framework to model explicitly the ways in which formal and informal institutions interact and to highlight two aspects of institutions: whether formal institutions are effective in what they claim to do; and whether the goals of agents in the formal and informal institutions are compatible and mutually reinforcing or incompatible and in conflict with each other. We follow Helmke and Levitsky (2003) in placing informal institutions center-stage; these range from bureaucratic and legislative norms to various forms of clientelism or reliance on business or familial networks rather than formal access to banks. In neglecting these informal institutions, one risks ignoring many of the real incentives and constraints that underlie the functioning of firms in emerging economies. We use the Helmke and Levitsky framework to classify the way in which informal institutions relating to corporate governance function in China and India as compared with Russia and Brazil and to contrast the effects of these informal-formal institutional interactions on corporate governance.

The main contribution of this paper is to provide a sharper theoretical framework, which has formerly been applied in the area of political science, to economic theorizing on formal and informal institutions with specific theorizing on how informal institutions work. It is a first step in the process of making the boundary between the formal and informal institutions theoretically and empirically sharper, to address the question of how the interactions of informal and formal institutions have been beneficial in some contexts and detrimental in others. This paper provides a preliminary framework through which to address this question. It provides an understanding in terms of the consistency between the formal objectives of the governance institutions and how those institutions operate in practice.

Our work provides a useful first step in organizing the disparate literature on formal and informal institutions, and clarifies some of the contrasting relationships found in emerging economies as to how these institutions interact and affect governance. However we acknowledge that there are also some limitations to this framework. The first is that it is essentially static, and one needs to think about mechanisms to explain movements from one state to another. The second is that one needs to build on the framework in order to make the hypotheses that arise from this analysis empirically measurable. The third is the lack of clarity as to the level of analysis which the framework should employ. However, our analysis leads us to believe that the framework nonetheless yields considerable insights and that these limitations should therefore be regarded primarily as a stimulus for further research. To that end, we revisit these issues at greater length in the concluding section, alongside how future work might address them. 
In The Helmke-Levitsky typology of informal institutions we outline the framework and classification of different types of informal institutions, before discussing Formal institutions of corporate governance. The role of informal institutions in corporate governance structures in the BRIC countries assesses the effectiveness of formal corporate governance institutions and examines the role of informal institutions in corporate governance and contrasts their functioning between China, India, Brazil, and Russia. Conclusions summarizes our findings on a grid that places the BRIC countries' institutions according to the role of their informal institutions in corporate governance. We go on to discuss how stable these positions are and the possible directions of movement following institutional reform.

\section{The Helmke-Levitsky typology of informal institutions}

Helmke and Levitsky (2003) build on the ideas of Douglass North (1991) and describe informal institutions as "the actual rules that are being followed," unwritten rules that often shape incentives in systematic ways. Informal rules have long been of interest but have not been rigorously conceptualized or theorized into mainstream studies of institutions which have focused rather on the formal rules of the game. Formal institutions refer to state bodies such as courts, legislatures, bureaucracies, and state-enforced rules such as constitutions, laws, and regulations. They are openly codified in that they are established and known through official channels. Informal institutions are usually unwritten and are created and enforced outside the official channels.

They argue that informal institutions can work either positively or negatively to boost or constrain formal institutions. For example in the sphere of political science, informal institutions may limit presidential power; despite Chile's 1980 Constitution creating one of the most powerful presidencies in the world, in practice Chilean presidents have been constrained by a complex network of informal institutions that push for executive consultation and power-sharing. Informal devices in Costa Rica lead legislators to perform constituency services that parties need for electoral campaigns. Informal institutions can also undermine formal regimes: clan networks and politics in the Kyrgyz Republic and Uzbekistan subverted formal institutions in the post-Soviet era after 1990 such that "informal mechanisms of network-controlled exchange and norms ... became the rules of the game." We are therefore grouping under informal institutions a variety of structures which have significance in the economy but whose power does not stem from de jure rights.

The focus of the Helmke-Levitsky framework is on the interaction between formal and informal institutions. There are two strands of the literature. In the first, informal institutions have a problem-solving role in assisting social interaction and coordination and improving the efficiency or performance of complex formal institutions. In the other, informal institutions have a problem-creating role, for example via corruption, clientelism, or clan politics that undermine markets, states, and democratic regimes. Peng (2001) stresses the role of institutional frameworks rather than national cultures and specifically the positive role of market-supporting institutions, both formal and informal, in giving rise to entrepreneurship in China. Morck (2005), Morck and Steier (2005), and Steier (2009) highlight the rent-seeking 
behavior and stifling of new entrants that can occur when large family business groups entrench themselves, particularly in emerging economies.

Helmke-Levitsky provides a systematic framework to model how under certain conditions informal institutions will reinforce failing formal institutions whereas under others informal institutions will undermine formal institutions. They identify four distinct types of informal institutions in terms of the way they interact with the formal: complementary, accommodating, competing, and substitutive. This typology is based on two characteristics. The first is the effectiveness of formal institutions, with two aspects: whether there are laws and codes of governance which exist de jure and are marketsupporting and whether these de jure laws and codes of conduct are enforced. If, due to judicial inefficiency or corruption, formal rights are not matched by enforcement, then those formal institutions are said to be ineffective. Informal institutions can operate in a context of effective formal institutions where good rules exist and are enforced, or informal institutions can work in a context of non-existence of clear rules or rules which are not enforced. Only when legal rights on paper are matched by de facto enforcement, which can come about through formal or informal institutional means, can we argue that those formal institutions are effective.

The second characteristic of informal institutions concerns the degree of compatibility between the goals of the actors relevant to formal and informal institutions. Goals are compatible at a particular level of analysis if the aims of the formal laws and the agents working within informal institutions - be they business groups, familial networks, the state through the local party, bureaucratic elites - are working towards the same ends, for example, the financing of companies or the reinforcement of corporate ownership rights. Incompatible goals means that the aims of formal and informal agents at that level of analysis are hostile or, more weakly, are not mutually reinforcing. To give an example, where shareholder rights are contested by the state or where minority investor rights are threatened by expropriation, the goals of investors or shareholders are pitted against those agents in informal institutions such as the state or local party or oligarchic shareholder which are threatening expropriation.

The Helmke-Levitsky typology of informal institutions is shown in Table 1 where complementary informal institutions are defined by having a context of effective formal institutions and compatible goals between formal and informal. Informal institutions fill in the gaps left by formal institutions, are compatible and complementary to them, and assist them in functioning more effectively; they address problems not dealt with by formal rules yet without violating them. Hence they tend to enhance the performance or efficacy of the formal institutions. Helmke

Table 1 Typology of informal institutions.

\begin{tabular}{lll}
\hline & $\begin{array}{l}\text { Ineffective formal } \\
\text { institutions }\end{array}$ & $\begin{array}{l}\text { Effective formal } \\
\text { institutions }\end{array}$ \\
\hline $\begin{array}{l}\text { Compatible goals between actors in formal and } \\
\text { informal institutions }\end{array}$ & Substitutive & Complementary \\
$\begin{array}{l}\text { Conflicting goals between actors in formal } \\
\text { and informal institutions }\end{array}$ & Competing & Accommodating \\
\hline
\end{tabular}

Helmke and Levitsky (2003). 
and Levitsky give examples of such complementary informal institutions in the variety of norms and routines that allow bureaucracies to function efficiently such as the folkways of the US Senate. They are most commonly found in OECD countries where formal institutions function effectively. This is in some ways similar to the "Varieties of Asian Capitalism" literature (Carney, Gedajlovic, \& Yang, 2009a) which discusses institutional complementarities depending on the extent to which institutions (in several sectors) are compatible with one another. Liberal market economies and coordinated market economies are characterized as having high levels of complementarity with mutually supportive interconnected institutions. In contrast, hybridized or mixed models of capitalism, such as more nearly describe those in emerging economies in Asia, have non-cohesive institutions that work against one another.

Accommodating informal institutions arise in situations where formal institutions are effective but the goals of formal and informal actors are in conflict. Such informal institutions act to reconcile the interests of the key actors with the formal arrangements, getting around formal rules when they are not in line with the aims of all actors. Thus, they violate the spirit rather than the letter of formal rules and provide a second-best solution where the rules cannot be challenged directly. They do not necessarily enhance performance but they can create stability and enable the functioning of the formal institutions. Examples might include the operation of a large scale shadow economy in countries with a well-developed property rights systems but also high levels of business taxation and regulation.

Substitutive informal institutions occur where formal institutions are ineffective but goals between formal and informal are compatible. Thus they subvert the formal rules and there is connivance between actors in formal and informal institutions in getting around what are commonly perceived to be inadequate or inappropriate formal institutions providing alternative methods of institutional functioning. In doing so, they can improve performance and create vested interests in those substitutive informal institutions. Again parallels can be drawn with the "Varieties of Capitalism" literature; Carney and colleagues (2009a), Carney, Shapiro, and Tang (2009b) argue that the organization of firms into business groups in many Asian countries is due to the absence of formal institutions that can assure business transactions; business groups trading repeatedly with one another establish quasi markets for capital, talent, technology, and other resources that are costly or inaccessible through market contracting. These groups are acting as substitutes for market institutions and their actions fill these institutional voids.

Competing informal institutions exist where there are ineffective formal institutions and conflicting goals between formal and informal actors. Here the informal institutions actually challenge formal institutional structures; those acting through informal institutions have differing goals from the actors within the formal institutions. These kinds of informal institutions can include corruption networks such as mafias, clientelism, or various forms of clan-like networks, arbitrary inspection teams which can extort rents and work on a differently functioning system of power and incentives from those actors operating within formal institutional frameworks. In doing so they can undermine those formal institutions and could tend to diminish or reduce measures of performance such as entry of new firms or levels of FDI, measures which rely on a level playing field between incumbent firms and new firms or between domestic 
entrepreneurship and foreign entrepreneurship. Carney and colleagues (2009a, b) and Steier (2009) also point to the scenarios of oligarchic capitalism where business groups may become so large and powerful within their national economies that they inhibit the ability of new firms to form or independent firms to grow. This would constitute an example where the informal institution of the business group is replacing the ineffective formal institution (capital markets which are insufficiently developed to give firms access to finance) but where the goals of the large and powerful business groups are incompatible with the formal institutional goals of providing access to all firms, small as well as large and new as well as incumbent ones. Steier (2009) contrasts the characteristics of an oligarchies-dominated system, with little entrepreneurship, wealth preservation, and rent-seeking and the perpetuation of weak institutions, with an entrepreneurial-dominated system where business groups act for wealth creation and where institutional voids are bridged by such groups and the institutional environment is developing. As Steier (2009: 531) says, "whether familial capitalism contributes to or inhibits the prosperity of an economy depends largely on the institutional context," and "we need to develop better theories of how organizations, institutions and economies co-evolve."

\section{Identifying relevant informal institutions in the BRIC countries}

The informal institutions that we identify as relevant to our discussion of the functioning of corporate governance institutions are specific to each country and are identified from the literatures on the histories and legacies of each country. A strong component of the story is that the interactions between formal and informal institutions in the economic sphere are path dependent, arising out of the modes of development that are characteristic of that country.

In China, we focus on the role that the state plays in legitimizing private property and entrepreneurship in the absence of effective formal legal rights as a key informal institution. This heralds back to Sachs and Woo (1994), who contrast the paths of reform in China and Russia emphasizing the very different starting points when transition from planning occurred. Specifically, Chinese liberalization was a process that continually involved the local state. Property ownership involved quasicontracts with the state to deliver a negotiated amount of taxes, leaving incentives to produce more which could be retained by the enterprise. The reforms were not conceived as an integrated strategy to create a market, still less a capitalist economy, at best perhaps a socialist market economy from 1992. The formal legal institutions were not therefore conceived or designed as those to support a capitalist market economy. Nevertheless the process of gradual reform (Laffont \& Qian, 1999) placed emphasis on engineering an accommodation to reform, to reduce constraints to enterprise, and to reinforce the market processes without formally having to forego the political ideology of state control.

In Russia, the informal institution that is central to the operation of governance, as in other workings of the economy, is the tradition of "blat" (Andvig, 2006; Ellman, 1978; Ledeneva, 1996), with its elaborate code of gift-giving and obligation, sliding into corruption. In practice, this has so far proved more continuous and stronger than the institutions of the more formal market-based governance arrangements. It is argued (Sachs \& Woo, 1994) that in part this has to do with the more deeply 
entrenched roots of the planning economy in Russia than in China and therefore of ways of dealing with its constraints. The blat system has endured well beyond the collapse of the Soviet system and it is on this that we focus below.

In Brazil, the shadow (informal) institution that we identify is the operation of the informal economy. This emerges out of the analyses following de Soto and Llosa (1989) that stresses the response to the "bureaucratized and law-ridden state" in Latin America through the informal institution of the shadow economy which works around formal rules in a parallel economy that is freer and unregulated. We follow this literature in looking specifically at how the informal economy operates in the realm of corporate governance in its interaction with formal governance institutions.

Finally, for India, the key informal institution that we have identified again is identified from the literature in which informal institutions are most significant. In India's case, the role of business groups in economic and business development has been particularly highlighted (Carney, 2008; Douma, George, \& Kabir, 2006; Khanna \& Palepu, 2000), historically arising when licensing and state restrictions were the norm (Shiba \& Masahiro, 1997). The role of diversified (conglomerate) business groups, usually family owned and closely held, is a persistent characteristic of Indian growth (Chacar \& Vissa, 2005).

\section{Formal institutions of corporate governance}

Shleifer and Vishny (1997), in their survey of corporate governance, propose the main issues for corporate governance in emerging economies to be: (1) the nature of legal protection for investors, particularly small minority investors where they exist, and (2) the concentrated ownership of firms and the presence of large investors in firms that are the norm for developing country ownership structures and the consequences of concentrated ownership and influence of large investors. As Broadman (1999) argues, we need a broader prism to assess control and corporate governance in emerging economies than simply the relationship between providers of equity capital and those running firms; the Berle and Means (1932) model of entrenched management and weak dispersed shareholders is not the issue. In emerging economies there is frequently concentrated ownership and a dominant shareholder, be they an individual, family, institutional investor, or a bank. The problem for closely held firms is not one of shareholder protection and boards of directors but of cross-shareholdings, holding companies, and pyramid mechanisms which the dominant shareholders use to exercise control, namely the principalprincipal issue, (Young, Peng, Ahlstrom, Bruton, \& Jiang, 2008). In other words the dominant shareholder is often over-powerful and exploits the other stakeholders in the firm. Broadman (1999) has termed this for Russia "unchecked insider control" in a corporate governance vacuum without well-protected property rights. The related problem of insider control is that of transparency of information-it is often highly unclear who are the ultimate owners of, for instance, Russian corporate shares in the rise of the closely held firm. This is true also for China. As Peng (2002) points out, firm boundaries in many Asian economies (as well as in Russia) are often blurred by the existence of large conglomerates, permeated by personal connections, partial 
ownerships, and board interlocks. The ownership patterns of such business groups are therefore more opaque than in Western firms.

The BRIC countries, as most emerging economies, are characterized by corporate governance structures with high concentration of ownership and inside investors (Gerlach, 1992; Heugens, van Essen, \& van Oosterhout, 2009). The consequences of the potential principal-principal problems that follow from concentrated ownership depend largely on the way the key institutions, formal and informal, in the country work. In particular, as discussed above, the formal legal protection of minority shareholders is critical in protecting against self-dealing by dominant shareholder-executives. It is also a question of the extent, in practice, that the country's institutions allow dominant shareholders to extract benefits from the firms that they own and control. As Heugens and colleagues (2009) argue, there are three ways that inside investors who combine a substantial ownership stake with direct managerial control over a company might adversely affect firm performance. They might be more risk averse than more diversified investors and hence less profit-generating; they might appoint family members whom they trust or can exert influence over rather than outsiders with more managerial experience and talent; and they may exploit minority shareholders by tunneling funds out of the corporation. The quality of a country's institutions, formal and informal, will affect the extent to which these problems occur; both the formal legal protection of minority shareholders and also the extent to which dominant shareholders are able to extract benefits from the firm in practice.

The Helmke-Levitsky framework can be applied at the level of particular institutions and agents within those institutions. When analyzing ownership structures of firms, the appropriate level of analysis is the security of property rights for those owners in each particular country, for example owners of firms in the context of an Indian family-held business group, or a Russian financial-industrial group, or a Chinese formerly stateowned firm. When looking at the assurance of returns to investors and its interplay with access to finance, the appropriate level of analysis is that of the firms themselves and the institutional mechanisms that are available to ensure those returns and thereby to raise capital. In other words, how do capital markets and banks operate in each country, which kinds of firms have access to them, what are the alternative informal institutions that function to provide such finance, and what is their relationship to the formal institutions, as looked at from the perspective of those firms in each country. In each case, we specify who those agents are, how the goals of agents in the specific formal and informal institutions are compatible or incompatible, and whether the formal institutions are effective or ineffective in relation to the goals of those formal institutions. We find some but not complete consistency within countries in terms of the way informal and formal institutions interact.

\section{Formal corporate governance structures in BRIC countries}

China's formal legal corporate governance structures are ineffective as marketsupporting institutions in several ways. In fact, private ownership of property only became legally permissible relatively recently: In 1977 private firms were illegal and negligible in numbers, by 2005 there were 29.3 million private businesses, employing over 200 million people and accounting for almost 50\% of GDP (China Daily, 2005, in Tsai, 2006). This is despite the fact that property rights in China were not formally 
recognized until 2004 and legal independence of the judiciary has been poor ( $\mathrm{New}$ York Times, 2005). There is a lack of legal infrastructure, shaky intellectual property rights (IPR), and weak contract enforcement (Cao, 2004). There also remains considerable state ownership of privately listed companies and the state or its agents carry out shareholder functions which would otherwise be performed by private owners in market economies (Estrin \& Tian, 2008; Tian \& Lau, 2001). There are various studies of the state's incapability as a shareholder (Broadman, 1999; Chen, 1997) Corporate governance codes do not conform to those of the West in a variety of ways: there is frequent CEO-chairman duality with no independent chairman of boards of directors and directors on boards tend to be affiliated and not independent of management. Overall, formal ownership governance structures are not particularly conducive to effective corporate governance (see Table 2).

India's formal corporate governance institutions were very poor post-independence but have improved somewhat since the 1991 liberalization: capital markets have been liberalized, a takeover code adopted in 1994 paving the way for a rudimentary market in corporate control, and steps have been taken to improve corporate governance norms and disclosure practices. Foreign capital has increased (see Goldman Sachs, 2003). Following La Porta, Lopez-de-Silanes, Shleifer, and Vishny (1998), we can classify India according to its formal codes of legal/regulatory institutions and different levels of investor protection; these are formal measures of investor protection (Table 2). We can conclude that India's formal shareholder and creditor rights are relatively well formulated within a well-established legal framework.

However, as noted above, a distinctive feature is the prevalence of conglomerate business groups entailing common ownership and management by family members; firms are separate legal entities, listed separately with their own set of shareholders, but the family controls the strategic direction and regulates firm transfers (Douma et al., 2006). It has been widely argued that business groups have filled institutional voids such as imperfections in markets for capital, products, and managerial talent (Khanna \& Palepu, 2000). Peng and Jiang (2006) provide evidence that concentrated ownership is beneficial for firm performance in cases where there are weaker or less developed legal and regulatory institutions to protect shareholders.

Table 2 Formal shareholder rights and creditor rights.

\begin{tabular}{lll}
\hline & $\begin{array}{l}\text { Shareholder rights } \\
\text { Index }\end{array}$ & $\begin{array}{l}\text { Creditor rights } \\
\text { Index }\end{array}$ \\
\hline India & 5 & 4 \\
Brazil & 3 & 1 \\
US & 5 & 1 \\
Average across sample & 3 & 2.3 \\
China & Low $^{\mathrm{a}}$ & Low $^{\mathrm{a}}$ \\
Russia & High $^{\mathrm{a}}$ & High $^{\mathrm{a}}$ \\
\hline
\end{tabular}

La Porta and colleagues (1998).

${ }^{a}$ Author estimation (Estrin \& Prevezer, 2010). 
Moreover, India has marked differences between regions. Although national legal structures and policies apply in all states, there are marked variations in the implementation of the legal system at the state level. Thus high-performing states such as Gujarat or Maharashtra have $8 \%$ per annum growth rates in state GDP compared with $4 \%$ per annum and lower rates in Bihar or Orissa. In poorlyperforming states, security of property, ownership rights, and enforcement of the rule of law are poor and formal legal codes are ineffective.

Russian laws on corporate governance and property rights were constructed from scratch in the late 1980s. Puffer and McCarthy (2003) list the laws affecting corporate governance including the legalization of private companies (1986), through to the 1991 Law on Property and 1992 Law on Privatization of State Enterprises, the 1996 Joint Stock Company Law strengthening shareholder rights, the 1996 Law on the Securities Market strengthening corporate governance including the protection of minority shareholders and the separate roles for the CEO and Chairman. However, serious issues remained in practice because of lax enforcement and failure to protect minority shareholder rights, creditor rights, and the balance between debtors and creditors in bankruptcy hearings, plus a lack of transparency in bankruptcy and company law (Puffer \& McCarthy, 2003). A new Russian Bankruptcy Law was introduced in 1998. Reforms in 2000 led to improvement in transparency and the implementation of international accounting standards for many firms, and competition law in 2002 strengthened norms and rules governing contracts (McCarthy, Puffer, \& Naumov, 2000). The independence of the judiciary was strengthened through a law of 2001 on the status of judges removing judicial appointments from control by regional legislatures, and there was a new Criminal Procedure Code of 2002 increasing the power of judges. The security of property rights was scrutinized by parliament in 2003 and minority shareholder rights were strengthened in 2004 (Granville \& Leonard, 2007). The Russian Federation is now classified as a "high compliance country" in terms of level of compliance with international standards for corporate governance, indicating a sound legal framework in line with OECD principles (EBRD, 2005). As Table 2 shows, formal institutions for corporate governance in Russia can now be regarded as good.

In Brazil, formal corporate governance structures have improved markedly since 2000 (Lubrano, 2007). The negative consequences of poor governance (noted in Table 2) were apparent with considerable legal uncertainty and an overhang of nonvoting shares and poor company performance. There was a legal reform initiative, a World Bank and IFC study, and an Investor Task Force in 2000. Since then there have been some milestones: an OECD Roundtable launch, a companies/investors meeting, and the launch of the Novo Mercado all in 2000, approval of legal reforms in 2001, the taking off of the Novo Mercado in 2004, an International Corporate Governance meeting in 2004, a Banco Real Corporate Governance Credit Line also in 2004, a Companies Circle in 2005, and the 100th Novo Mercado listing in 2007. By 2007 there were demonstrable consequences of improved corporate governance: most new shares now go out on the Novo Mercado and there is greater legal certainty in changes of control but some obstacles to takeovers. There are public and private sector champions for good governance and leadership in most elements of the private sector among companies and investors. The legal framework including enforcement infrastructure is in place and there is also the private infrastructure in terms of 
education and monitoring; more recent offerings by restructured firms would not have been possible without these reforms (Lubrano, 2007).

Formal institutions for external investment

Access to equity markets is relatively low across all the BRIC countries, with a greater reliance on internal funds and insider investment than on external investors. Reliance on equity markets is particularly low in Brazil at around 3-4\% of firms compared with $12-$ $16 \%$ of firms in India and China, and access to long-term finance through international capital markets is restricted to larger firms. This is the consequence of the underdeveloped nature of capital markets as much as poor governance structures.

The greatest sources of external finance are from banks through overdraft facilities or bank loans, with much greater access for larger firms than small- to medium-sized enterprises (SMEs). In Brazil in particular, terms are more severe for SMEs with low volumes of credit given, higher interest rates, and high default rates and terms are more favorable to incumbent, established firms in older industries than newly created firms (Campos \& Iootty, 2007). More than half of Brazilian firms that need loans do not apply, according to a World Bank (2003a, b, c) report because of the complex requirements, compared with a figure of $32 \%$ for China and $16 \%$ for India. The problem is particularly severe for micro firms where the Brazilian level is three times that of Chinese or Indian firms (see Appendix Table A1).

In China, state-owned firms have preferential access to finance from state-owned banks compared with private firms; there are severe restrictions to bank loans for certain types of businesses, especially privately owned and riskier enterprises. In India, the position is more favorable for smaller firms, with over half of small businesses having active bank credit lines or overdraft facilities and a lower reliance on retained earnings than in China or Brazil. Russia's position on formal access to finance is poor. Russian companies in the early 2000 s obtained only 3-5\% of capital from banks, compared with $15-30 \%$ in more advanced market-based countries. The reason is that banks controlled very little of the country's banking deposits, with Alfa Bank for example holding only $2-3 \%$ of Russia's ruble deposits. Sberbank, owned by the Central Bank, controlled $72 \%$ of the country's ruble deposits in 2002 and favored larger and state-owned firms (Puffer \& McCarthy, 2003). Use of external finance for SMEs is low: the OPORA survey of SMEs stated that only $16 \%$ of small businesses across Russia use bank loans (OPORA, 2005). Formal external investor rights in the BRIC countries are therefore weaker than in the West because of less reliance on external investment. This in turn is due to the historical legacy of state-owned banks which do not themselves have a market-supporting legacy as institutions.

\section{The role of informal institutions in corporate governance structures in the BRIC countries}

This paper develops a framework to analyze consequences of the fact that informal institutions play a greater role in corporate governance in emerging economies than in OECD economies (Peng \& Heath, 1996). This role is ambiguous however: informal institutions can improve the functioning of corporate governance or they can undermine 
the formal corporate governance institutions, and we see both patterns across the BRIC economies. In contrast, the bulk of informal institutions are probably usually complementary in most OECD economies.

We will argue below that in China and India, the informal institutions for corporate governance are largely substitutive in that they compensate for ineffective formal corporate governance institutions but the goals are not in conflict with those of the formal institutions. However, Russia has competing informal institutions for corporate governance in that the effectiveness of the formal institutions is undermined through corruption and lack of enforcement and the goals of the agents in informal institutions conflict with the goals of formal institutions. Interestingly Brazil has accommodating informal institutions for corporate governance in that the effectiveness of the formal institutions is largely good, but informal institutions have different goals from the formal institutions and are used to get around what are seen to be overly restrictive formal institutions.

In terms of overall effectiveness of their formal corporate governance institutions, we see, in Table 3, a distinction between India, China, and Russia where effectiveness is low due to weak rule of law, poor enforcement, and high corruption, and Brazil where effectiveness overall is high, apart from the inefficiency of its judiciary, with a strong rule of law, strict enforcement, medium levels of corruption, and a low risk of expropriation.

China

A favorable environment for firms and creating supportive goals between owners and local states and government officials (Ahlstrom, Bruton, \& Yeh, 2008) has been constructed in China via informal institutions in a variety of ways. The informal institutions that compensate for unclear corporate ownership and rights of investors are those that build the legitimacy of private firms in the face of uncertain legal rights (Ahlstrom et al., 2008). As Ahlstrom and colleagues quote "There's nothing to keep the [Chinese] Government from taking those private assets back ... One year things are open and everyone can prosper; the next year the Government decides to collect everything for the state" Cao Si-yuan, senior adviser to former People's Republic of China General Secretary Zhao Ziyang. The perceived governance danger in China is

Table 3 How effective are formal corporate governance institutions.

\begin{tabular}{lllll}
\hline Enforcement measures & Judiciary & Rule of law & Corruption & Risk of expropriation \\
\hline India & 8 & 4.17 & 4.58 & 7.75 \\
Brazil & 5.75 & 6.32 & 6.32 & 7.62 \\
China & weak $^{\mathrm{a}}$ & weak $^{\mathrm{a}}$ & poor $^{\mathrm{a}}$ & low $^{\mathrm{a}}$ \\
Russia & weak $^{\mathrm{a}}$ & weak $^{\mathrm{a}}$ & poor $^{\mathrm{a}}$ & high $^{\mathrm{a}}$ \\
US & 10 & 10 & 8.63 & 9.98 \\
Average of sample & 7.67 & 6.85 & 6.90 & 8.05 \\
\hline
\end{tabular}

La Porta and colleagues (1998).

${ }^{a}$ Author estimation (Estrin \& Prevezer, 2010). 
therefore not misappropriation or tunneling by concentrated owners vis á vis minority shareholders (although this may be an issue). Instead it is establishing private ownership rights as against the state, where the default position is that the state may assume ownership and control of all assets. For instance, many private businesses in China were founded before it was legal to possess private property, or when it was legal but bypassed many of the bureaucratic regulations for such businesses, combining state and private assets. The owners of private companies fear that the government might challenge their right to exist and appropriate assets. In the light of this, Ahlstrom and colleagues (2008) emphasize the various types of informal institutions that are used to establish legitimacy and to protect the firm in the light of unclear or ineffective formal institutions. These include cultivating relations with government officials, taking over ailing state-owned enterprises, donating services to the local community, and concealing the private nature of ownership (Ahlstrom et al., 2008).

Tipton (2009) argues that the Chinese state since the 1980s has the attributes of fairly high state direction (although lower than in the earlier period) alongside low state capacity and the ability to enforce the legal regime. According to Wang Hongying (2000) Chinese legal institutions have been either ineffective or irrelevant. Private ownership of companies has only relatively recently been made legal and has remained politically less favored than state or collective ownership and there remain ambiguities in enforcement of private ownership rights, which are susceptible to government intervention and expropriation. As Heugens and colleagues (2009) argue, China combines a situation of weak ownership protection and weak rule of law, in which concentrated ownership ceases to substitute and be an effective corporate governance strategy.

However, informal institutions can neutralize or compensate for these weaknesses in shareholder protection and rule of law. Tsai (2006) emphasizes "adaptive informal institutions and endogenous institutional change in China" in the area of private ownership of companies. Informal interactions between the local state and private entrepreneurs have underpinned and legitimized formal institutional reforms in favor of private property rights. The formal institution of state ownership has remained in place in many cases while the substantive role has changed dramatically. There has been "institutional conversion" where actors "quietly appropriate formal institutions to serve their own ends" (Tsai, 2006) when there is a gap between the original intentions of the formal institutions and the aims of local actors. This institutional adaptation or conversion can only occur when there is a convergence of aims and incentives between the enforcers of formal institutions and the creators of informal adaptations, in this case the local state and private owners of companies. Both local state and private owners mutually benefit from arrangements that transgress the formal institutional rules, and have ignored or not enforced those rules, creating substitutive institutions of private company ownership. For example, this has been done through disguising private ownership - wearing a red hat (dai hongmaozi) - where a business is registered as a collective enterprise whereas in practice it is privately owned and managed; or registering a private enterprise as an appendage to a state-owned one, a so called hangon enterprises (guahu qiye). Red hat enterprises were particularly prevalent in the first decade of reform when privately-owned enterprises with more than eight employees were illegal. In many localities over $90 \%$ of collective enterprises were privately-owned but with disguises of red hats. Local party officials have been complicit in sanctioning 
this arrangement. In the Eastern provinces of Fujian and Zhejiang, large numbers of private firms were registered as collectives to avoid stifling regulations and have remained registered as such (Huang, 2005; Wank, 1996), whereas in Guangdong province, with its longer acceptance of private enterprise, these concealment strategies have not been so necessary.

Formal regulation of private enterprise has adapted to these informal arrangements by legalizing their existence. From 2001, private entrepreneurs were invited to join the Chinese Communist Party. However, Party members continued to use the disguise of wearing a red hat as there remained political criticism of private entrepreneurs" "spiritual pollution" and "bourgeois liberalization" and harassment by tax collectors and bureaucrats. Tsai (2006) gives an example of a furniture manufacturer in Hebei province that had run a state-owned enterprise as a Communist Party member for 12 years; he set up his own business in 1991 under the disguise of a red hat, registering it as a collective enterprise. He continued in the local People's Congress and was heralded as an "upstanding red capitalist."

Other strategies that firms have taken to build the legitimacy of their private enterprise include choosing geographical localities where it is known that private enterprise is more acceptable; by taking over ailing state-owned enterprises especially in poorer regions of the country in order to gain approval from both the provincial government and from the central government; through using very long-standing relations or clan ties which confer legitimacy; through reciprocal relation-building including giving gifts and holding receptions (Peng \& Luo, 2000); allying with foreign firms whose legitimacy was already accepted and whose presence was welcomed; through establishing guanxi with local officials, party cadres, village committees, and the judiciary (Ahlstrom et al., 2008). For example, visits by senior government officials have been seen as conferring approval and have lead to preferential terms for bank loans and government support.

In terms of relationships between investors more generally and the firm, Chinese capital markets are under-developed and banks continue to be state-owned and dominated by local state funding priorities. Chinese family-owned firms rely heavily on informal sources of finance such as family networks (Appendix Table A1), particularly small private firms with lack of access to bank finance. Entrepreneurs go to unofficial and illegal credit institutions, not qualifying for credit from state-owned banks which favor strategically important firms at the expense of SMEs. Private credit and underground credit institutions have flourished, relying on personal connections and reputation and SMEs have to borrow from such illegal institutions at very high rates (Tian, 2007). Again these informal institutions are countenanced officially and are seen not to conflict with the aims of formal legal institutions.

\section{India}

In India, despite shareholder and creditor rights formally having been well set up, there are issues in terms of how effectively these rights are enforced. We noted that in part this is a regional issue, with some states having effective legal rights and in others (such as Bihar) the rule of law not being well established. Overall, as Table 3 shows, in terms of effectiveness, India fares poorly on the rule of law and corruption indices compared with the average in the sample, although the efficiency of the judiciary is good and the risk of expropriation is low. Lee and Oh (2007) distinguish between the pervasiveness and 
arbitrariness of corruption, arguing that pervasive corruption without arbitrariness does not detract from growth and investment, in that it is predictable and can be built into firms' calculations of cost. Arbitrary corruption on the other hand, even with fairly low levels of pervasiveness, is off-putting to investors, especially foreign investors, in that its uncertainty and unpredictability make dealings more hazardous. They place China and India as both having pervasive corruption, but India having arbitrary corruption in addition, which would tend to undermine formal institutions and place greater onus on the role of the informal institutions in the governance of firms.

In India, we would argue that the most important informal institutions, to interact with these formal governance institutions, are those associated with business groups. We discussed above the extensive ownership and control of firms by families and business groups in many Asian countries, including India. The issue for this paper concerns what role these groups play - do they fill an institutional void by giving access to resources through informal, private networks, or do family-controlled firms discriminate against outside shareholders, have more difficult agency conflicts within the family, and lead to worse performance of firms from the point of view of shareholders? Douma and colleagues (2006) find positive effects on performance of concentrated corporate ownership by foreign and domestic corporations (as distinct from foreign or domestic financial institutions), in particular when affiliated to a business group. Peng and Jiang (2006) find that the net balance of benefits and costs of family ownership and control in large firms depends on the legal and regulatory institutions for investor protection: that high family ownership concentration is beneficial when formal legal institutions are weak. Heugens and colleagues (2009) supports this finding - that when there is less than perfect legal protection of minority shareholders, ownership concentration is an efficient corporate governance strategy. But they also find that a certain threshold level of institutional development is necessary to make concentrated ownership effective. Where owners can extract private benefits from the corporations they control, then such concentration is not beneficial to firm performance.

Li, Ramaswamy, and Pécherot Petitt (2006) argue that the business group structure is a horizontal strategy of diversification that is particularly suited for dealing with the market failures associated with failures in capital markets and in the managerial labor market. Capital markets in India fail because they are weak and shallow and limit any company's potential to obtain money to fuel expansion and growth (Khanna \& Palepu, 2005; Khanna \& Yafeh, 2005). In most emerging economies, equity is a small part of capital raised and access to debt capital is controlled by a handful of banks which act according to government priorities in the industrial sector. Usually access to foreign capital is relatively limited as well, due to weak governance norms (Li et al., 2006). Large business groups overcome financing obstacles, creating an internal capital market and enabling the different firms within it to compete for funds.

This summary of the literature as well as our cases (Estrin \& Prevezer, 2010) lead us to conclude that the informal institutions of corporate governance in India are substitutive - that they replace the largely ineffective formal legal framework and capital markets but have non-conflicting aims or goals with those of formal institutions. This applies mainly in those states where the rule of law, crime, and corruption are not so arbitrary as to create conflicting goals between the business groups and the formal legal framework. 


\section{Russia}

Although Russia's formal corporate governance codes on paper are comparable to OECD standards, its formal institutions are ineffective due to lack of enforcement and a gap between the "virtual economy" (Maddy \& Ickes, 1998) reflected in official statistics and company reports and reality. In practice, the concentrated financial industrial groups (FIGs) owned by so-called "oligarchs" (Estrin, Poukiakova, \& Shapiro, 2009) have been rent-seeking and stifling of entrepreneurship (Aidis, Estrin, \& Mickiewicz, 2008) and have conflicting aims with the formal rules of the legal framework and institutions.

As Heugens and colleagues (2009) argue, for ownership concentration to be beneficial for the performance of firms, there needs to be a certain degree of institutional development as measured by the rule of law in the absence of strong legal protection of minority shareholders. In the case of Russia, the formal rule of law and protection of minority shareholders is undermined by lack of enforcement and arbitrary corruption. The identity of the concentrated shareholder also matters; Heugens and colleagues (2009) distinguish between market (arm's-length) investors, stable investors such as affiliated firms or banks with multiple ties to the firm, and inside investors who combine concentrated ownership with managerial control. They find that different kinds of concentrated owners have different effects on performance. If there are strong formal institutions in the form of effective rule of law, then even if there is low protection for minority investors, there is a spread of returns between market and other investors as market investors can nevertheless rely on recourse to the courts to enforce their rights against tunneling. This is not the case in Russia, with insider investors, ineffective rule of law, and a weak judiciary. It is argued that even with a clear legal claim, there is a danger of losing assets through the corruption of the judicial system and administration. The Yukos affair illustrated the selectiveness of the application of the law and insecurity of shareholding rights (Luo, 2007).

The private benefits (tunneling) of concentrated shareownership and control can come in various ways: formal legal protection can be circumvented by dominant shareholders through the lack of capacity or willingness to monitor corporate governance. There may be opportunities for tunneling through corruption in enforcement of codes, in the recognition of formal ownership rights, in the operation of the courts, in the ability of the government to take on the dominant owners, or through transfer prices of assets being negotiable, or providers of assets or products being negotiable (Heugens et al., 2009).

Russian companies are characterized by inside investors, combining concentrated ownership with managerial control in part as a result of the way in which privatization occurred.

The failure of the rule of law in the 1990s, primarily due to non-enforcement, gave rise to enormous freedom for enterprise managers to conduct business. This allowed managers to enrich themselves by legitimate but also illegitimate means - through dishonesty, manipulation, and criminality (Puffer \& McCarthy, 2003). Accountability for enterprise directors broke down in the 1990s and excesses and abuses have stemmed from that period. Privatization was carried out in 1993 and 1994 - initially through a voucher system that was manipulated in favor of existing enterprise directors (Estrin \& Wright, 1999) and managers were able to buy shares from workers and others at low prices which did not reflect the potential value of such ownership. Newly entrenched managerowners were able to use their concentrated ownership to abuse minority shareholder 
rights and rights of joint venture partners through asset stripping and capital flight. These managers combined dominant ownership positions with managerial control and hence no constraints either on managerial behavior or on dominant inside shareholder power existed. There was privatization but with no supporting institutions to create a culture or mentality of accountability (Earle, Estrin, \& Leshchenko, 1996). What Puffer and McCarthy (2003) call the nomenklatura stage in the late 1990s depicts the control over the economy going to the business-government elite with a number of privileged players enriching themselves and the emergence of a number of leading oligarchs. This consisted in a reciprocally lucrative alliance between bureaucrats and businessmen and the creation of powerful financial industrial groups including Menatep, Onexim, Inkombank, and Alfa (see Estrin et al., 2009).

Core shareholders have disproportionate influence on management and both are able to take advantage of minority shareholders. The abuses of shareholder rights have occurred in primitive ways such as not allowing shareholders to come to meetings, taking shareholders' names off registers, and forcing them to fight it out in the Russian courts (Fyodorov, 2001), diluting capital by issuing stock to majority shareholders, non-compliance with disclosure requirements, unfair transfer pricing, unlawful transactions, and fictitious bankruptcies (Puffer \& McCarthy, 2003). The loans-for-shares scheme in 1995 was a further abuse whereby leading oligarchs gained further shareholder power in exchange for supporting Yeltsin's reelection. This is described as an incestuous relationship between top businessmen and government officials with no transparency, accountability, or disclosure (Puffer \& McCarthy, 2003). Since the crisis of 1998, there has been increasing state involvement in business affairs. It is argued by Buck (2003) that this marks a return to centuries-old involvement and direction by the state in Russian business affairs and that the hostility to outside investors, especially foreign investors, also has long historical roots. It is rare for any company to have more than $20 \%$ of its shares in free float and available for purchase. State influence has consisted in strong personal links between private owners of the blue-chip mainly non-manufacturing companies and the government; the Ministry of State Property still remained a majority shareholder in over 12,000 state-owned enterprises and a minority shareholder in over 3,800 companies in 2002; the state held $38 \%$ of shares in Gazprom, valued at $8 \%$ of Russia's GDP in 2002, and assets are managed via state boards composed of members of ministries and agencies (Buck, 2003).

Despite some signs of Putin attempting to restore greater accountability and protection of minority shareholders, since the early 2000 s there has been a movement of additional government involvement as a solution to corporate governance abuses. However, government involvement in business affairs, despite passing a new code of corporate conduct in 2002, has led to further abuses of power and lack of independence of the judiciary from the state. The entanglement between the government and Yukos has increased the impression of corruption in corporate governance.

The distinctive similarity between China and Russia lies in the role of the state considered in both cases as a type of informal institution in the sense that the state's rules are not clear, stable, codified, nor transparent in either case. But the difference between them lies in the non-conflicting complementary goals that the state has vis á vis company owners, in China-both company owners and local states are more interested in fostering economic growth and both will do or not do whatever is necessary to gain 
legitimacy to achieve this. This in large part means a de facto enforcement of ownership rights and various types of regulation. The Russian state does not have mutually complementary goals with most large concentrated owners of firms - its enforcement of laws is seen as arbitrary and hostile to the independent running of companies; there is a sometimes antagonistic relationship between the government and oligarchs and corruption takes the form of arbitrary inspections, asset stripping, lack of independence of the courts and their use for going after business leaders out of line with government policies. Moreover, large concentrated owners do not have complementary goals with minority shareholders. Corporate governance abuses therefore come from both the concentrated inside ownership with abuse of minority shareholders through asset stripping, capital flight, tunneling of benefits out of the firm, and through abuses by the Russian government in its involvement in business affairs and in its use of the rule of law vis á vis large oligarchic shareholders.

\section{Brazil}

Tables 2 and 3 indicate good formal corporate governance indices for Brazil comprising quite good shareholder rights, strong rule of law, and low risk of expropriation and there has been an improvement in corporate governance codes. However, there is a weak judiciary and weaker investor rights than the average for the sample. Nevertheless, corruption is not arbitrary (Appendix Table A3) although the judiciary is inefficient: Brazil's laws allow many appeals so that even fairly trivial cases end up in high courts, with enormous backlogs and huge delays. Life is difficult for companies that pay taxes and comply with labor laws so Brazil has a large black economy. Companies in the formal economy are forced to abide by expensive and enforced rules (Economist, 2009).

All measures of regulation of firms and its enforcement place Brazilian firms as very highly regulated in the formal economy (Appendix Table A2), especially with regard to regulations over hiring and firing labor. This forms part of a wider corporate governance picture of tightly enforced formal laws and regulations leading to the rise of the informal economy with the aim of getting around those rules. The World Bank Doing Business survey ranked Brazil $150^{\text {th }}$ out of 183 countries in ease of paying taxes, hiring and firing is complicated, and on ease of starting and closing a business Brazil placed 37 out of 43 countries surveyed by the World Bank (World Bank, 2005). Dyck and Zingales (2004) estimate the value of private benefits extracted by dominant shareholders across a sample of countries. Their estimates range from close to zero for most OECD countries (but not all) to $65 \%$ of firm equity in Brazil.

We conclude that the effectiveness of formal institutions in corporate governance in Brazil is high in that the rules are good and enforced. Our argument is that they are too tightly enforced and that this gives rise to the pervasive informal institution of the shadow economy - both companies opting out of formal legal obligations and entering the black economy and tunneling out of formal companies by shareholders in a position to do so. Thus the character of Brazil's informal institutions derives from its large black economy and the role of informal institutions is to get around formal rules. Brazil therefore has accommodating informal institutions in that there are effective formal but incompatible goals between formal and informal institutions. What we mean by this is that informal institutions - of corruption, of the black economy - are engaged in getting around the 
formal rules that are perceived to be overly enforced and over-tight. They do not undermine the formal rules but find ways of reconciling the conflicting aims of one group with another.

\section{Conclusions}

Corporate governance structures in the BRIC countries are complex. In all four countries, we find relatively concentrated ownership structures and not much in the way of protection of minority shareholders. In Brazil and Russia however, the legal framework for corporate governance looks quite good on paper whereas in China and India the legal framework does not look clear-cut. Ownership rights in China particularly are neither protected nor especially transparent; it is advantageous to disguise an enterprise's ownership as being state-owned or collectively-owned when in fact there is a private entrepreneur or family behind the scenes. India's formal legal framework is more transparent, but less so in terms of where actual control resides because of pervasive family or group control. The implications of this diversity in corporate governance ownership-control structures is also varied, and here the role of informal mechanisms comes to the fore. In practice, ownership structures function fairly well in China due to the compensating ways whereby there is de facto recognition of ownership rights by the state and government, and particularly in China, encouragement to foreign investors and assurance that ownership rights will be respected. In India, control by business groups substitutes to some extent for the weak formal arrangements In contrast, in Russia, despite formal legal protection for all shareholders, including minority ones, in practice there is poor law enforcement, arbitrary corruption, and undermining of minority rights, in particular by leading shareholders and managers, and an unclear relationship between large corporate owners and the government. This means that there is fear of expropriation, of arbitrary enactment of laws in retrospect, and of no redress for grievances through the courts and it is unclear what mechanisms exist to control managerial behavior.

We summarize the relationship between the formal and informal institutions in terms of their effects on these aspects of corporate governance in the following way.

Figure 1 indicates where we would place these corporate governance institutions of the BRIC countries in terms of type of informal institutions they possess. China and some states in India, despite ineffective formal institutions, have informal mechanisms that compensate and replace them-substitutive informal institutions - that promote positive investment outcomes both domestically in terms of entrepreneurship and in relation to foreigners leading to strong flows of FDI, particularly in China. We have placed emphasis on the differing types of substitutive informal institutions that operate in India compared with China - the role of business groups in India and that of the relationship with the state and local government in China. Business groups operate as well in China (Carney et al., 2009b), but the role of the state in organizing them around state-owned enterprises and the role of government policy in promoting them as substitutive institutions, brings out the state role in China as the most important type of substitutive institution in this period. In contrast Brazil, with largely effective formal institutions, has an accommodating informal framework that works in parallel, but with incompatible goals, to the formal institutions and acts to subvert the nature of regulation as upheld by the formal rules. Finally, Russia is in the worst position as regards investment outcomes, despite formal institutions and governance codes being 


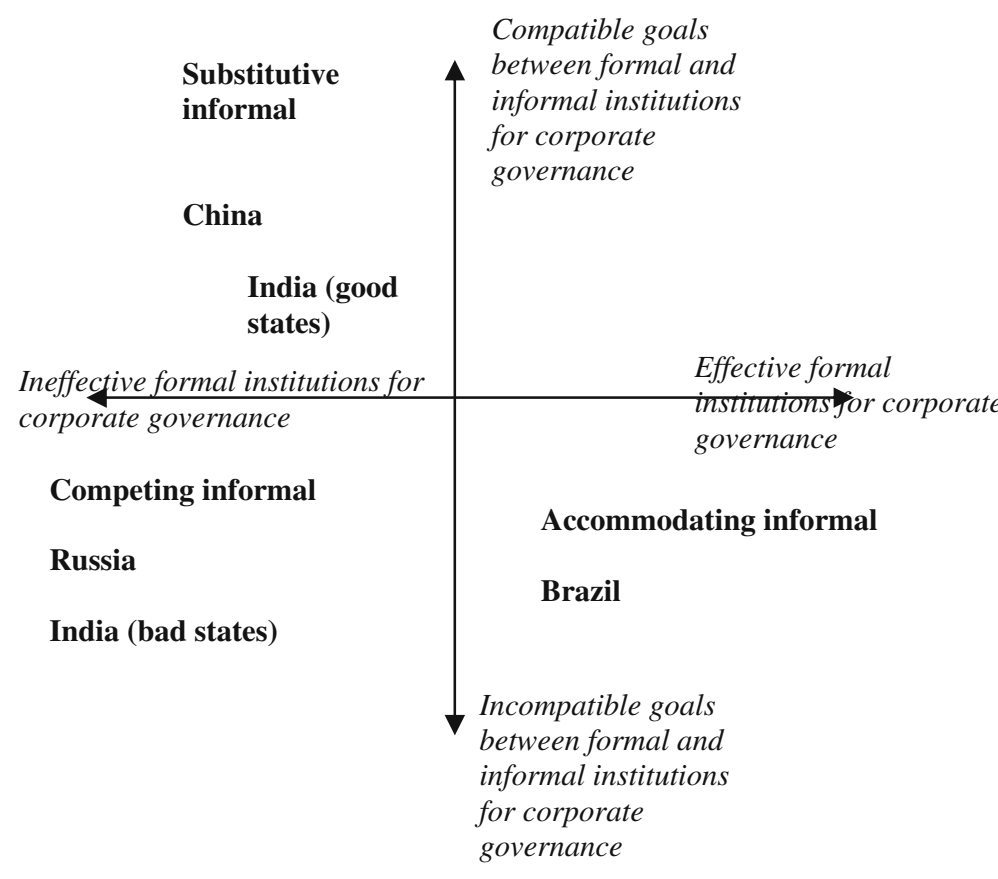

Figure 1 Corporate governance institutions in BRIC countries in the Helmke-Levitsky framework

respectable on paper, because in practice informal institutions of networks (blat) between leading shareholders, the business groups, and the State compete with the formal arrangements.

\section{Contribution of this study and its limitations}

Our main contribution lies in the potential of this framework for theoretical and empirical research which brings to the forefront the analysis of informal institutions and how their interaction with particular formal rules and institutions can have profound effects on governance, company performance, and business environment.

Our approach highlights the tensions in thinking about how corporate governance practices may affect economic performance, both in emerging economies receiving FDI from companies headquartered in developed countries and in host countries receiving FDI from firms whose headquarters are in emerging economies. How exportable or intrinsic to the operation of these companies are the corporate governance practices that are formed in their home countries? Does the influence of these informal institutions in our BRIC emerging economies carry through to companies headquartered in developed countries, or to companies undertaking FDI outside these particular emerging economies? In other words how intrinsic to the particular country are these interactions between informal and formal institutions or to what extent are they embodied within practices within companies that may not remain rooted within those particular countries?

This gets to the nub of some of the problems in developing our thinking about the influence of this interaction between informal and formal institutions, in the sphere of 
governance and the limitations of this framework for doing so. The framework provides a first step in bringing together informal and formal institutions and it organizes the interaction along the dimensions of effectiveness and compatibility. What it does not yet do is provide a systematic formulation of which is the applicable perspective or lenswhether policy-maker, manager, labor, creditor, consumer, or shareholder-through which to view these interactions. Indeed, our analysis of the BRIC countries suggests that there is no single appropriate perspective through which to view these interactions. We would argue that the particular informal institutions relevant to governance measures should be identified through reference to the histories and literatures relating to each particular country. Hence the perspective to be adopted in each case has to be identified in relation to the particular impact that these informal institutions have in different governance areas, in turn related to where the particular weaknesses lie in effectiveness of formal institutions. So for example in China, the literature suggests that security of ownership has been the governance area most requiring mediation through the informal institution of the state. Hence the appropriate perspective or level of analysis is through the owners of companies - shareholders, those owning and controlling enterprises, be they domestic or foreign owners. The question to ask through this perspective is what difference does the stance of the local state make to company owners in terms of their security of tenure from expropriation, security in the face of legalistic uncertainty. For Russia, where the key informal institution has been identified as the operation of blat networks, the perspective and level of analysis should be through an analysis of those networks and how they intersect with ownership and control arrangements. So for an understanding of the working of governance in Russia and how formal rules interact with informal, it would be important to pinpoint empirically who shareholders of companies are, the extent of their interlocks across companies, the composition of networks, and to get some handle on how these networks cut across formal rules and how they compete with official institutions. In similar fashion for India, the relevant perspective for understanding the interaction of formal and informal would be that of how the business group intersects with the formal company shareholder, to understand its influence in terms of structure of ownership-how large are business group shareholdings, how extensive across companies, how extensive internationally, what access to financial resources do they bring, and many other similar questions which would enrich our understanding of how governance works in that country. For Brazil the perspective would need to have a lens to how access to the informal economy operates on companies - empirically, do companies use the informal economy and for what kinds of work, how is the use of informal unregulated resources viewed by the official authorities, how restrictive on performance is using informal resources.

Our framework can also be used to think about some of the wider issues of convergence or divergence of corporate governance arrangements. This requires recognizing and integrating the influence of these particular informal institutions on more dynamic and recent aspects of governance. So for example thinking about inward or outward FDI and the transferability of governance arrangements requires analysis of whether those informal institutions are rooted in the host economy or travel with the investing companies. Again, this will vary and will require empirical research. For example, the influence of business groups on governance arrangements is likely to be more mobile and transferable than the influence of the local Chinese state on Chinese outward investment, although the influence of the local state on companies undertaking 
inward FDI from developed countries is likely to be strong and would need to be understood as part of governance arrangements and its impact on company performance. Analysis of the potential for takeovers or minority investments in Asian business would need to take account of how the informal institutions of business groups, blat, or the state will affect - reinforce, invalidate, or replace - the formal ownership stakes in companies and will in turn affect performance of those companies. We emphasize that it is a dimension that will need to be incorporated and taken into account with sensitivity as to which appropriate perspective will be required.

The value of our contribution lies in its organizing framework and its inclusion of informal institutions through their interaction with the formal institutional framework. We transfer the Helmke-Levitsky approach, which was applied in an ad hoc way to the political science sphere, to the economic institutional setting and apply it in a more systematic way to the existing debates about informal institutions and corporate governance in emerging economies. We emphasize that the relevant perspectives will vary according to the mode and on whom the informal institutions operate in each country. This opens up a huge research theoretical and empirical agenda as to how to operationalize the measurement of effects of the interaction of informal institutions on formal institutions and as to how to conceive the boundary conditions between the different types of informal institutions. Is there movement from one state to another; when do substitutive informal institutions become accommodating ones; is there a convergence process and through which agents does this operate; which are the more permanent fixtures in the informal institutional governance procedures and which may be more transient? We have made a few suggestions as to how one might begin to integrate the influence of informal institutions into the empirical measurement of governance arrangements, but this is the tip of the iceberg of a much broader research agenda that recognizes the penetrative influence and heterogeneity but historical specificity of the informal institutional effect on such arrangements.

\section{Appendix}

Table 4 Access to finance measures (proportion of firms with access to that type of finance 2003).

\begin{tabular}{|c|c|c|c|c|}
\hline & Brazil & India & China & Russia \\
\hline \multirow{3}{*}{$\begin{array}{l}\text { Access to } \\
\text { overdraft or } \\
\text { bank credit } \\
\text { lines or bank } \\
\text { loans }\end{array}$} & $\begin{array}{l}35-75 \% \\
\text { average }\end{array}$ & $\begin{array}{l}35-58 \% \\
\text { average }\end{array}$ & $\begin{array}{l}25-30 \% \\
\text { average }\end{array}$ & $\begin{array}{l}42 \% \text { large } \\
\text { firms }\end{array}$ \\
\hline & \multirow{2}{*}{$\begin{array}{l}\text { High end of } \\
\text { spectrum for } \\
\text { larger firms }\end{array}$} & $76 \%$ SMEs & 14\% SMEs & \multirow[t]{2}{*}{$16 \%$ SMEs } \\
\hline & & $\begin{array}{l}60 \% \text { micro } \\
\text { firms }\end{array}$ & $\begin{array}{l}6 \% \text { micro } \\
\text { firms }\end{array}$ & \\
\hline $\begin{array}{l}\text { Reliance on } \\
\text { internal funds } \\
\text { or retained } \\
\text { earnings }\end{array}$ & $43-53 \%$ & $30 \%$ & $53 \%$ & n.a. \\
\hline $\begin{array}{l}\text { Reliance } \\
\text { on equity }\end{array}$ & $3-4 \%$ & $16 \%$ & $11-12 \%$ & n.a. \\
\hline
\end{tabular}


Table 4 (continued).

\begin{tabular}{|c|c|c|c|c|}
\hline & Brazil & India & China & Russia \\
\hline $\begin{array}{l}\text { Informal } \\
\text { sources of } \\
\text { finance }\end{array}$ & $2-4.5 \%$ & $15-17 \%$ & $\begin{array}{l}15-27 \% \\
8 \% \text { large } \\
\text { firms }\end{array}$ & n.a. \\
\hline $\begin{array}{l}\text { External finance } \\
\text { as severe obstacle }\end{array}$ & $85 \%$ & $27 \%$ & $29 \%$ & n.a \\
\hline Interest rate spreads & $45 \%$ & n.a. & $3.3 \%$ & $8.5 \%$ \\
\hline
\end{tabular}

Various World Bank ICAs and EBRD transition reports.

Table 5 Various regulation measures (2002).

\begin{tabular}{lcccc}
\hline & Brazil & India & China & Russia \\
\hline Management time spent dealing with regulation & $8.1 \%$ & $14.2 \%$ & $8.1 \%$ & $9.5 \%$ \\
Labor regulations perceived as obstacle to growth & $57 \%$ & $17 \%$ & $19 \%$ & n.a. \\
Overstaffing (i.e., exit restrictions) & $3 \%$ & $11 \%$ & $19 \%$ & n.a. \\
Number of inspections per year & 7.8 & 6.7 & 26.7 & n.a. \\
Hiring indices & 67 & 33 & 11 & 0 \\
Firing indices & 70 & 90 & 40 & 2 \\
\hline
\end{tabular}

World Bank Doing Business data and ICAs.

Table 6 Corruption measures (2003-2004).

\begin{tabular}{lcccc}
\hline & Brazil & India & China & Russia \\
\hline \% of sales given to secure government contract & $12.2 \%$ & n.a. & $2.2 \%$ & $1.5 \%$ \\
Losses due to crime as share of sales & $0.6 \%$ & n.a. & $0.3 \%$ & $3 \%$ \\
\% firms seeing corruption as obstacle to growth & $67 \%$ & $38 \%$ & $27 \%$ & n.a. \\
Transparency International 2004 corruption perception index rank & 59 & 90 & 71 & 90 \\
\hline
\end{tabular}

Various World Bank ICAs and EBRD transition reports.

\section{References}

Acemoglu, D., \& Robinson, J. 2000. Political losers as a barrier to economic development. American Economic Review, 90: 126-130.

Acemoglu, D., Johnson, S., \& Robinson, J. 2001. The colonial origins of comparative development: An empirical investigation. American Economic Review, 91: 1369-1401.

Acemoglu, D., Johnson, S., \& Robinson, J. 2002. Reversal of fortune: Geography and institutions in the making of the modern world income distribution. Quarterly Journal of Economics, 12311294.

Acemoglu, D., Johnson, S., Robinson, J., \& Thaicharoen, Y. 2003. Institutional causes, macroeconomic symptoms: Volatility, crises and growth. Journal of Monetary Economics, 50: 49-123.

Aguilera, R. V., Filatotchev, I., Gospel, H., \& Jackson, G. 2008. An organizational approach to comparative corporate governance: Costs, contingencies, and complementarities. Organization Science, 19(3): 475-492. 
Ahlstrom, D., Bruton, G. D., \& Yeh, K. S. 2008. Private firms in China: Building legitimacy in an emerging economy. Journal of World Business, 43: 385-399.

Aidis, R., Estrin, S., \& Mickiewicz, T. 2008. Institutions, networks and entrepreneurship development in Russia: A comparative perspective. Journal of Business Venturing, 23(6): 656-672.

Andvig, J. C. 2006. Corruption and fast change. World Development, 34(2): 328-340.

Berle, A., \& Means, G. 1932. The modern corporation and private property. New York: Harcourt.

Broadman, H. 1999. Comments on ownership and control of Russian industry. Presented at the OECD, USAIS, and World Bank Conference on Corporate Governance in Russia, Moscow, Russia, May-June.

Buck, T. 2003. Modern Russian corporate governance: Convergent forces or product of Russia's history?. Journal of World Business, 38(4): 299-313.

Campos, N. F., \& Iootty, M. 2007. Institutional barriers to firm entry and exit: Case study evidence from the Brazilian textiles and electronics industries. Economic Systems, 31(4): 346-363.

Cao, C. 2004. Zhongguancun and China's high-tech parks in transition. Asian Survey, 46(5): 647-668.

Carney, M. 2008. The many futures of Asian business groups. Asia Pacific Journal of Management, 25(4): 595-613.

Carney, M., Gedajlovic, E., \& Yang, X. 2009a. Varieties of Asian capitalism: Toward an institutional theory of Asian enterprise. Asia Pacific Journal of Management, 26(3): 361-380.

Carney, M., Shapiro, D., \& Tang, Y. 2009b. Business group performance in China: Ownership and temporal considerations. Management and Organization Review, 5(2): 167-193.

Chacar, A., \& Vissa, B. 2005. Are emerging economies less efficient? Performance persistence and the impact of business group affiliation. Strategic Management Journal, 26: 933-946.

Chen, L. 1997. The models of restructuring the assets and some case studies. Research on Economics and Management (Jingji yu guanli yanjiu), 18(6): 32-37.

De Soto, H., \& Llosa, M. V. 1989. The other path: the invisible revolution in the Third World. New York: Harper and Row.

Djankov, S., La Porta, R., Lopez-de-Silanes, F., \& Shleifer, A. 2002. The regulation of entry. Quarterly Journal of Economics, 117: 1-35.

Douma, S., George, R., \& Kabir, R. 2006. Foreign and domestic ownership, business groups and firm performance: Evidence from a large emerging market. Strategic Management Journal, 27: 637-657.

Dyck, A., \& Zingales, L. 2004. Private benefits of control: An international comparison. Journal of Finance, 59(2): 537-600.

Earle, J., Estrin, S., \& Leshchenko, L. 1996. Ownership structures, patterns of control and enterprise behavior in Russia. In S. Commander, Q. Fan \& M. E. Schaffer (Eds.). Enterprise restructuring and economic policy in Russia. Washington, DC: World Bank.

Economist. 2009. Getting it together at last: A special report on business and finance in Brazil. November 14.

EBRD (European Bank for Reconstruction and Development). 2005. Transition report 2005. London: EBRD.

Ellman, M. J. 1978. The fundamental problem of socialist planning. Oxford Economic Papers, 30(2): 249262.

Estrin, S., Poukiakova, S., \& Shapiro, D. 2009. The performance of business groups in Russia. Journal of Management Studies, 46(3): 393-420.

Estrin, S., \& Prevezer, M. 2010. A survey on institutions and new firm entry: How and why do entry rates differ in emerging markets?. Economic Systems, forthcoming.

Estrin, S., \& Tian, L. 2008. Retained state shareholding in Chinese PLCs. Does government ownership reduce corporate value. Journal of Comparative Economics, 36(1): 74-89.

Estrin, S., \& Wright, M. 1999. Corporate governance in the Former Soviet Union: An overview of the issues. Journal of Comparative Economics, 27: 398-421.

Fyodorov, B. 2001. Speech at the American Chamber of Commerce in Russia Conference, April 26.

Gerlach, M. L. 1992. Alliance capitalism: The social organization of Japanese business. Berkeley: University of California Press.

Globerman, S., \& Shapiro, D. 2003. Governance infrastructure and US foreign direct investment. Journal of International Business Studies, 33(1): 19-39.

Goldman Sachs. 2003. Dreaming with BRICS: The path to 2050. Global Economics paper no. 99, Goldman Sachs, http://www.gs.com.

Granville, B. E., \& Leonard, C. S. 2007. Do institutions matter for technological change in transition economies?. Centre for Globalization Research working paper 4, Queen Mary University of London, London.

Helmke, G., \& Levitsky, S. (2003). Informal institutions and comparative politics: A research agenda. Working paper no. 307, Kellogg Institute for International Studies, University of Notre Dame, Notre Dame, Indiana. 
Heugens, P. P. M. A. R., van Essen, M., \& van Oosterhout, J. H. 2009. Meta-analyzing ownership concentration and firm performance in Asia: Towards a more fine-grained understanding. Asia Pacific Journal of Management, 26(3): 361-609.

Huang, Y. 2005. Selling China: Foreign direct investment during the reform era. Cambridge: Cambridge University Press.

Khanna, T., \& Palepu, K. 2000. Is group affiliation profitable in emerging markets? An analysis of diversified Indian business groups. Journal of Finance, 55(2): 867-891.

Khanna, T., \& Palepu, K. 2005. The evolution of concentrated ownership in India: Broad patterns and a history of the Indian software industry. In R. Morck (Ed.). The history of corporate governance around the world: Family business groups to professional managers: 283-320. Chicago: University of Chicago Press.

Khanna, T., \& Yafeh, Y. 2005. Business groups and risk sharing around the world. Journal of Business, 78 (1): 301-340.

Laffont, J. J., \& Qian, Y. 1999. The dynamics of reform and development in China: a political economy perspective. European Economic Review, 43(4-6): 1105-1114.

La Porta, R., Lopez-de-Silanes, F., Shleifer, A., \& Vishny, R. W. 1998. Law and finance. Journal of Political Economy, 106(6): 1113-1155.

La Porta, R., Lopez-de-Silanes, F., Shleifer, A., \& Vishny, R. W. 1999. The quality of government. Journal of Law, Economics and Organization, 15: 222-279.

Ledeneva, A. 1996. Between gift and commodity: The phenomenon of blat. Cambridge Anthropology, 19 (3): 43-67.

Lee, S.-H., \& Oh, K. K. 2007. Corruption in Asia: Pervasiveness and arbitrariness. Asia Pacific Journal of Management, 24(1): 97-114.

Li, M., Ramaswamy, K., \& Pécherot Petitt, B. S. 2006. Business groups and market failures: A focus on vertical and horizontal strategies. Asia Pacific Journal of Management, 23(4): 439-452.

Licht, A. N., Goldschmidt, C., \& Schwartz, S. H. 2005. Culture, law, and corporate governance. International Review of Law and Economics, 25: 229-255.

Lubrano, M. 2007. Corporate governance in Brazil: Observations on 2000-2007 and comparisons with other Latin American and BRIC markets. Washington: IFC/World Bank Corporate Governance Dept.

Luo, Y. 2007. Global dimensions of corporate governance. Malden, Ma: Blackwell Publishing.

Maddy, C. G., \& Ickes, B. 1998. Russia's virtual economy. Foreign Affairs, 77(5): 53-68.

McCarthy, S., Puffer, D., \& Naumov, A. I. 2000. Russia's retreat to statization and the implications for business. Journal of World Business, 35(3): 256-274.

Morck, R. 2005. The history of corporate governance around the world: Family business groups to professional advisors. Chicago: University of Chicago Press.

Morck, R., \& Steier, L. 2005. The global history of corporate governance: An introduction. In R. Morck (Ed.). The history of corporate governance around the world: Family business groups to professional advisors: 1-64. Chicago: University of Chicago Press.

New York Times. 2005. Rule by law: A series, by J. Kahn \& J. Yardley. New York Times, http://www. nytimes.com/ref/world/asia/rule index.html.

North, D. C. 1991. Institutions. Journal of Economic Perspectives, 5(1): 97-112.

OPORA. (2005). Conditions and factors affecting the development of small entrepreneurship in the regions of the Russian federation. http://www.opora.ru.

Peng, M. W. 2001. How entrepreneurs create wealth in transition economies. Academy of Management Executive, 15(1): 95-108.

Peng, M. W. 2002. Towards an institution-based view of business strategy. Asia Pacific Journal of Management, 19(1-2): 251-267.

Peng, M. W., \& Heath, P. 1996. The growth of the firm in planned economies in transition: Institutions, organizations and strategic choice. Academy of Management Review, 21(2): 492-528.

Peng, M. W., \& Jiang, Y. 2006. Family ownership and control in large firms: The good, the bad, the irrelevant - and why. William Davidson Institute working paper no. 840, William Davidson Institute, Ann Arbor, Michigan.

Peng, M. W., \& Luo, Y. 2000. Managerial ties and firm performance in a transition economy: The nature of a micro-macro link. Academy of Management Journal, 43(3): 486-501.

Puffer, D., \& McCarthy, S. 2003. The emergence of corporate governance in Russia. Journal of World Business, 38(4): 284-298.

Sachs, J., \& Woo, W. T. 1994. Structural factors in the economic reforms of China, Eastern Europe and the Former Soviet Union. Economic Policy, April, pp 102-145.

Shiba, T., \& Masahiro, S. 1997. Beyond the firm: Business groups in international and historical perspective. Oxford: Oxford University Press. 
Shleifer, A., \& Vishny, R. 1997. A survey of corporate governance. Journal of Finance, 52(2): 737-783. Steier, L. 2009. Familial capitalism in global institutional contexts: Implications for corporate governance and entrepreneurship in East Asia. Asia Pacific Journal of Management, 26(3): 513-535.

Tian, J. J., \& Lau, C.-M. 2001. Board composition, leadership structure and performance in Chinese shareholding companies. Asia Pacific Journal of Management, 18(2): 245-263.

Tian, L. 2007. Does government intervention help the Chinese automobile industry? A comparison with the Chinese computer industry. Economic Systems, 31(4): 364-374.

Tipton, B. 2009. Southeast Asian capitalism: History, institutions, states and firms. Asia Pacific Journal of Management, 26(3): 401-434.

Tsai, K. S. 2006. Adaptive informal institutions and endogenous institutional change in China. World Politics, 59: 116-141.

Wang, H. 2000. Informal institutions and foreign investment in China. The Pacific Review, 13(4): 525-556.

Wank, D. L. 1996. The institutional process of market clientelism: Guanxi and private business in a South China city. The China Quarterly, 147: 820-838.

World Bank. 2003a. Investment climate assessment Brazil 2003. Washington, DC: World Bank.

World Bank. 2003b. Investment climate assessment China 2003. Washington, DC: World Bank.

World Bank. 2003c. Investment climate assessment India 2003. Washington, DC: World Bank.

World Bank. 2005. Doing business report 2005. Washington, DC: World Bank.

Young, M. N., Peng, M. W., Ahlstrom, D., Bruton, G. D., \& Jiang, Y. 2008. Corporate governance in emerging economies: A review of the principal-principal perspective. Journal of Management Studies, 45(1): 196-220.

Saul Estrin (DPhil, Sussex University) is Head of the Department of Management, London School of Economics. Previously he was Adecco Professor of Business and Society at London Business School as well as Director of the Centre for New and Emerging Markets and Deputy Dean (Faculty and Research). He was the acting Dean of London Business School in 2000. He has published more than 150 books and papers. His main areas of research include transition economics and development, privatization and foreign direct investment. He is a Fellow of the Centre for Economic Policy Research (CEPR), Institute for the Study of Labor (IZA), and William Davidson Institute.

Martha Prevezer ( $\mathrm{PhD}$, London University) is senior lecturer at Queen Mary University of London, School of Business and Management. She has held positions as Research Fellow at London Business School's Centre for Business Strategy and Centre for New and Emerging Markets, Visiting Professor at City University, Reader in South Bank University Business School, and Economic Adviser at NEDO and the Bank of England. She has published two OUP books: Capital Markets and Corporate Governance and The Dynamics of Industrial Clustering, and many articles. Her research is on innovation, governance, and technological development in both developed countries and emerging markets. She looks at the emergence of new industries and technologies, new organizational structures in response to changing technologies, and the creation of firms and entrepreneurship and its relation to institutional development in emerging markets. 